\title{
THE IMPROVEMENT OF THE CURSIVE HANDWRITING SKILL THROUGH EXPLICIT INSTRUCTION MODEL (A CLASSROOM ACTION RESEARCH OF THE SECOND GRADE STUDENTS OF STATE PRIMARY SCHOOL SOROPADAN NO, 180 SURAKARTA IN ACADEMIC YEAR 2017/2018)
}

\author{
Linda Fitrianti, Sadiman, Matsuri \\ Universitas Sebelas Maret \\ lindafitrianti11@gmail.com
}

\section{Article History}

accepted 09/07/2018

approved 01/08/2018

published 17/09/2018

\section{Keywords}

writing skill, cursive handwriting, Explicit Instruction model

\begin{abstract}
The objective of this research is to improve the cursive handwriting skill through Explicit Instruction model of the second grade students. The type of this research was Classroom Action Research conducted two cycles. Each cycle consisted of four phases, namely: planning, acting, observing, and reflecting. The subjects of this research are teacher and second grade students which amounted to 31 students. The data of this research were collected by observation, interview, test, and documentation. The data of this research were validated by using data source and technique triangulations. The data were analyzed by using the interactive analysis model. Based of the research, seen from minimum passing score 70, the classical passing score of students writing skill was increased, from $29 \%$ in pre-action, increased to $61 \%$ in cycle I, and increased to $84 \%$ in cycle II. This research can be concluded that through Explicit Instruction model can improve cursive handwriting skill of the second grade students of State Primary School Soropadan No. 108 in academic year 2017/2018.
\end{abstract}

Social, Humanities, and Education Studies (SHEs): Conference Series

p-ISSN 2620-9284 https://jurnal.uns.ac.id/shes

e-ISSN 2620-9292 


\section{PENDAHULUAN}

Bahasa Indonesia memiliki kedudukan dan fungsi yang penting bagi bangsa Indonesia. Selain sebagai bahasa resmi dan bahasa persatuan, bahasa Indonesia juga berperan penting dalam pendidikan di Indonesaia. Dalam bidang pendidikan, bahasa Indonesia berperan penting untuk menunjang keberhasilan semua bidang studi karena pada dasarnya semua mata pelajaran menggunakan pengantar bahasa Indonesia kecuali bahasa daerah dan bahasa asing. Berdasarkan hal tersebut, maka sangat penting khususnya bagi siswa untuk menguasai bahasa Indonesia dengan baik. Di sisi lain, bahasa Indonesia juga merupakan mata pelajaran yang wajib dikuasai oleh siswa, sehingga mata pelajaran ini diajarkan sejak pendidikan usia dini bahkan hingga perguruan tinggi.

Pada jenjang pendidikan dasar terutama di sekolah dasar, bahasa Indonesia diajarkan secara terarah dan sistematis karena siswa sekolah dasar baru belajar bahasa. Menurut Zulela (2012) menyatakan bahwa pada hakikatnya pembelajaran Bahasa Indonesia di sekolah dasar diarahkan untuk meningkatkan kemampuan siswa agar dapat berkomunikasi secara lisan maupun tulisan dengan baik. Sesuai dengan Kurikulum Tingkat Satuan Pendidikan (KTSP) pembelajaran Bahasa Indonesia pada jenjang SD/MI mencakup empat keterampilan berbahasa, yaitu: keterampilan mendengarkan, keterampilan berbicara, keterampilan membaca, dan keterampilan menulis. Keempat keterampilan berbahasa merupakan satu kesatuan sehingga harus dikuasai secara urut dan berkesinambungan agar siswa dapat menyerap informasi dan berkomunikasi secara lisan maupun tulisan dengan baik.

Keterampilan berbahasa khususnya keterampilan menulis merupakan keterampilan yang penting untuk dikuasai oleh siswa di sekolah dasar. Rukayah (2013) berpendapat bahwa keterampilan menulis merupakan suatu kecakapan seseorang dalam menyampaikan pesan yang disampaikan melalui lambang bahasa baik dalam bentuk formal maupun non-formal kepada penerima pesan sehingga pesan yang disampaikan dapat dimengerti maksud dan maknanya. Keterampilan menulis penting untuk diajarkan karena digunakan sebagai sarana berkomunikasi secara tertulis. Selain itu, pada setiap pembelajaran kegiatan menulis selalu dilibatkan seperti menulis catatan, menyalin, dan mengerjakan sebagian besar tugas sekolah. Tanpa memiliki keterampilan menulis yang baik, siswa akan kesulitan dalam melaksanakan kegiatan pembelajaran. Oleh karena itu, pembelajaran keterampilan menulis di sekolah dasar harus benar-benar mendapatkan perhatian khusus dari guru.

Pada jenjang sekolah dasar pembelajaran keterampilan menulis dibedakan menjadi dua, yaitu: menulis permulaan yang diajarkan pada kelas I-II sekolah dasar dan menulis lanjut yang diajarkan pada kelas III-VI sekolah dasar. Menulis permulaan merupakan pembelajaran menulis yang diajarkan pertama kali sebagai bekal untuk menulis selanjutnya, yakni menulis lanjut. Menulis permulaan pada dasarnya berbentuk menulis menggunakan tangan. Pada tahap ini, siswa diajarkan menulis dengan tangan sesuai dengan kaidah penulisan agar dapat menghasilkan tulisan yang baik, jelas, dan mudah dibaca. Menurut Indira dan Vijayan (2015) menyatakan bahwa menulis tangan adalah keterampilan yang sangat penting bagi semua orang sebagai bagian integral (seluruh bagian) dari komunikasi bahkan di masa sekarang era komputer. Praktik tulisan tangan adalah kunci dalam pembelajaran motorik yang diperlukan untuk membentuk huruf dan angka dengan benar.

Pada menulis permulaan di kelas II sekolah dasar terdapat Kompetensi Dasar (KD) menulis tegak bersambung. Menurut Thompkins (1995) menulis tegak bersambung adalah menggabungkan huruf-huruf secara bersamaan untuk membentuk kata dengan satu gerakan tangan yang bersambung. Adapun alasan perlunya pembelajaran menulis tegak bersambung seperti yang dikemukakan oleh Abdurrahman (2012) adalah: (1) tulisan tegak bersambung memudahkan siswa untuk mengenal kata-kata sebagai suatu kesatuan, (2) melalui menulis tegak bersambung 
dapat mencegah siswa menulis terbalik-balik, dan (3) menulis dengan huruf tegak bersambung melatih siswa menulis lebih cepat karena tidak ada gerakan pensil yang terhenti untuk setiap hurufnya.

Menulis tegak bersambung sangat penting dikuasai oleh siswa sehingga harus diajarkan secara berkesinambungan dan teratur hingga siswa benar-benar terampil. Sharp dan Brown (2015) menyatakan bahwa ketika siswa diajarkan menulis tegak bersambung dengan cara positif dan informatif, mereka dapat (a) secara bersamaan mengembangkan kemampuan membaca, kemampuan berkomunikasi, dan keterampilan motorik halus; (b) menunjukkan kemudahan pemikiran yang lebih kuat dalam komunikasi tertulis; (c) dan memiliki lebih banyak cara menulis secara efisien. Namun, pada kenyataannya kondisi ideal pembelajaran menulis tegak bersambung tidak selalu sama dengan kondisi di lapangan, misalnya kondisi di SD Negeri Soropadan No. 108. Berdasarkan hasil wawancara (21 Desember 2017), observasi (4 Januari 2018) dan tes pratindakan (5 Januari 2018) diperoleh fakta bahwa permasalahan yang dialami oleh sebagian besar siswa kelas II adalah kesulitan dalam menulis tegak bersambung. Permasalahan ini disebabkan oleh metode mengajar guru yang kurang bervariasi karena hanya menekankan metode demonstrasi saja, perbedaan kemampuan siswa, dan perbedaan tingkat intelegensi siswa. Proses pembelajaran yang dilaksanakan hanya berpusat pada guru dan hanya terjadi komunikasi satu arah. Guru hanya memberikan contoh sekali kemudian siswa menirukannya, setelah itu siswa mengerjakan tugas menulis tegak bersambung, sehingga siswa kurang latihan menulisnya. Sebagian siswa memang dapat mengikutinya, tetapi sebagian yang lainnya tidak bisa mengikuti dengan baik karena perbedaan kemampuan dan tingkat intelegensi dari masing-masing siswa. Selain itu, pada hasil nilai tes pratindakan dari 31 siswa dengan KKM sebesar 70, menunjukkan bahwa sebanyak 9 siswa (29\%) yang mendapatkan nilai di atas KKM, sedangkan 22 siswa $(71 \%)$ mendapatkan nilai di bawah KKM atau belum tuntas.

Pada dasarnya mengajarkan menulis tegak bersambung seharusnya dilakukan dengan pencontohan melalui prosedur selangkah demi selangkah dan latihan yang intensif. Hal ini dikarenakan pengajaran menulis tegak bersambung pada dasarnya mengajarkan pengetahuan yang bersifat deklaratif dan prosedural. Permasalahan tersebut harus segera diatasi karena jika dibiarkan keterampilan menulis tegak bersambung siswa akan terus rendah dan akan berdampak pada keterampilan menulis pada tingkat selanjutnya. Oleh karena itu, harus segera diberikan solusi alternatif salah satunya dengan menerapkan model pembelajaran Explicit Instruction.

Eggen dan Kauchak (2012) mendefinisikan Explicit Instruction sebagai model yang menggunakan peragaan dan penjelasan yang digabungkan dengan latihan dan umpan balik untuk membelajarkan siswa tentang pengetahuan dan keterampilan nyata yang dibutuhkan untuk pembelajaran lebih jauh. Model Explicit Instruction efektif diterapkan pada siswa yang berprestasi rendah dan mengalami kesulitan belajar. Langkah-langkah model pembelajaran Explicit Instruction adalah: (1) Establishing set, yaitu guru menjelaskan tujuan pembelajaran dan mempersiapkan siswa, (2) Demonstrating, yaitu guru menjelaskan dan mendemonstrasikan pengetahuan atau keterampilan, (3) Guided practice, yaitu guru merencanakan dan memberikan instruksi kepada siswa mengenai latihan yang akan dilakukan keterampilan serta memonitor dan memberikan bimbingan jika diperlukan, (3) Feed back, yaitu guru melakukan pengecekan terhadap pemahaman siswa serta memberikan umpan balik, dan (4) Extended practice, yaitu guru memberikan kesempatan latihan mandiri dengan memberikan tugas.

Berdasarkan uraian di atas, maka permasalahan dalam penelitian ini dapat dirumuskan sebagai berikut: "Apakah penerapan model pembelajaran Explicit Instruction dapat meningkatkan keterampilan menulis tegak bersambung pada siswa kelas II SD Negeri Soropadan No. 108 Surakarta tahun ajaran 2017/2018?". 
Berdasarkan rumusan permasalahan tersebut, maka tujuan penelitian ini adalah untuk meningkatkan keterampilan menulis tegak bersambung melalui penerapan model pembelajaran Explicit Instruction pada siswa kelas II SD Negeri Soropadan No. 108 Surakarta tahun ajaran 2017/2018.

\section{METODE}

Penelitian ini dilaksanakan di SD Negeri Soropadan No. 108 Surakarta. Waktu penelitian adalah selama tujuh bulan, yaitu bulan Desember 2017 sampai Juni 2018, pada tahun ajaran 2017/2018. Bentuk penelitian ini adalah Penelitian Tindakan Kelas (PTK). Subjek penelitian ini adalah guru dan siswa kelas II yang berjumlah 31 siswa yang terdiri dari 17 siswa perempuan dan 14 siswa laki-laki. Sumber data dalam penelitian ini adalah guru dan siswa kelas II, silabus, RPP, serta dokumen selama pembelajaran. Teknik pengumpulan data yang digunakan adalah observasi, wawancara, tes, dan dokumentasi. Validitas data yang digunakan adalah triangulasi sumber dan teknik. Teknik analisis data yang digunakan yaitu model analisis interaktif yang terdiri dari pengumpulan data, reduksi data, penyajian data, dan penarikan kesimpulan. Prosedur penelitian ini dilaksanakan dua siklus dengan dua pertemuan setiap siklusnya. Pada setiap siklusnya terdiri dari 4 tahapan, yakni perencanaan, pelaksanaan tindakan, observasi, dan refleksi.

\section{HASIL DAN PEMBAHASAN}

Berdasarkan permasalahan yang ditemukan mengenai rendahnya keterampilan menulis tegak bersambung pada siswa kelas II SD Negeri Soropadan No. 108 Surakarta, maka dilakukan tindakan untuk meningkatkan keterampilan menulis tegak bersambung siswa. Berdasarkan pada fakta-fakta yang ditemukan di lapangan, peneliti memberikan alternatif solusi dengan menerapkan model pembelajaran Explicit Instruction. Perbaikan pembelajaran keterampilan menulis tegak bersambung melalui model pembelajaran Explicit Instruction dilaksanakan dalam 2 siklus yang terdiri dari 2 pertemuan setiap siklusnya. Pelaksanaan tindakan pada siklus I pertemuan 1 dilaksanakan pada tanggal 6 April 2018, sedangkan pertemuan 2 dilaksanakan pada tanggal 7 April 2018. Pelaksanaan tindakan pada siklus II pertemuan 1 dilaksanakan pada tanggal 11 April 2018, sedangkan pertemuan 2 dilaksanakan pada tanggal 18 April 2018.

Berdasarkan hasil tindakan siklus I dan siklus II melalui model pembelajaran Explicit Instruction, dapat dilihat perbandingan peningkatan nilai keterampilan menulis tegak bersambung dalam Tabel 1. sebagai berikut:

Tabel 1. Perbandingan Nilai Terendah, Nilai Tertinggi, Nilai Rata-rata, Ketuntasan Klasikal pada Pratindakan, Siklus I dan Siklus II

\begin{tabular}{llccc}
\hline No & \multicolumn{1}{c}{ Keterangan } & Pratindakan & Siklus I & Siklus II \\
\hline 1. & Nilai Terendah & 31,5 & 44 & 58 \\
2. & Nilai Tertinggi & 81,5 & 83 & 95,5 \\
3. & Nilai Rata-rata & 57 & 69,12 & 80,42 \\
4. & Ketuntasan Klasikal & $29 \%$ & $61 \%$ & $84 \%$ \\
\hline
\end{tabular}

Berdasarkan Tabel 1. dapat dijelaskan melalui grafik pada Gambar 1. sebagai berikut.

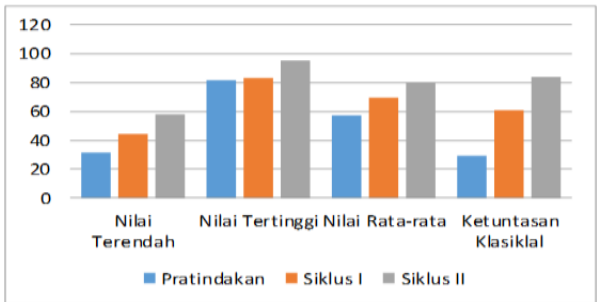

Gambar 1. Grafik Perbandingan Nilai Terendah, Nilai Tertinggi, Nilai Rata-rata pada Pratindakan, Siklus I dan Siklus II 
Selain meningkatkan nilai keterampilan menulis tegak bersambung siswa, melalui model pembelajaran Explicit Instruction juga meningkatkan kinerja guru dan aktivitas siswa. Berdasarkan hasil observasi dan analisis data kinerja guru dalam proses pembelajaran dapat diketahui bahwa terjadi peningkatan skor kinerja guru dari siklus I hingga siklus II.

Tabel 2. Perbandingan Skor Rata-rata Kinerja Guru Antarsiklus

\begin{tabular}{clcccc}
\hline \multirow{2}{*}{ No } & \multirow{2}{*}{ Keterangan } & \multicolumn{2}{c}{ Siklus I } & \multicolumn{2}{c}{ Siklus II } \\
& & Pert. 1 & Pert. 2 & Pert. 1 & Pert. 2 \\
\hline 1. & Skor Rata-rata & 2,88 & 3,08 & 3,23 & 3,38 \\
2. & Kategori & Baik & Sangat & Sangat & Sangat Baik \\
3. & Rata-rata & \multicolumn{2}{c}{ Baik } & Baik & \multicolumn{2}{c}{3,33} \\
4. & Kategori & \multicolumn{2}{c}{ Baik } & \multicolumn{2}{c}{ Sangat Baik } \\
\hline
\end{tabular}

Berdasarkan Tabel 2. tersebut dapat dijelaskan melalui grafik dalam Gambar 2. sebagai berikut:

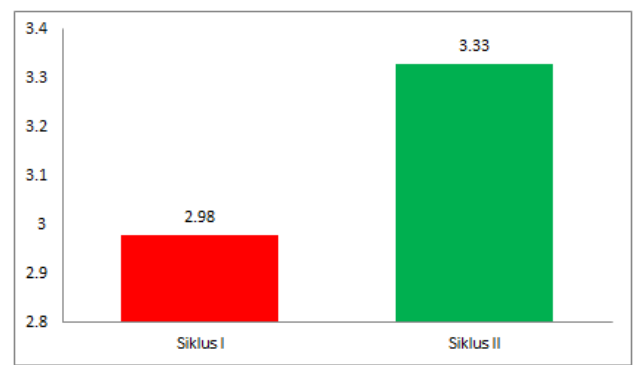

Gambar 2. Grafik Perbandingan Skor Rata-rata Kinerja Guru Antarsiklus

Berdasarkan hasil observasi aktivitas siswa mulai dari siklus I hingga siklus II mengalami peningkatan. Adapun perbandingan hasil observasi dari siklus I dan II akan disajikan dalam Tabel 3. sebagai berikut.

Tabel 3. Perbandingan Skor Rata-rata Aktivitas Siswa Antarsiklus

\begin{tabular}{clcccc}
\hline \multirow{2}{*}{ No } & \multirow{2}{*}{ Keterangan } & \multicolumn{2}{c}{ Siklus I } & \multicolumn{2}{c}{ Siklus II } \\
& & Pert. 1 & Pert. 2 & Pert. 1 & Pert. 2 \\
\hline 1. & Skor Rata-rata & 2,78 & 2,98 & 3,31 & 3,51 \\
2. & Kategori & Baik & Baik & Sangat & Sangat Baik \\
3. & Rata-rata & \multicolumn{2}{c}{2,87} & & \multicolumn{2}{c}{3,41} \\
4. & Kategori & \multicolumn{2}{c}{ Baik } & & Sangat Baik \\
\hline
\end{tabular}

Dari tabel 3. di atas dapat diperjelas dengan grafik pada gambar 3. di bawah ini.

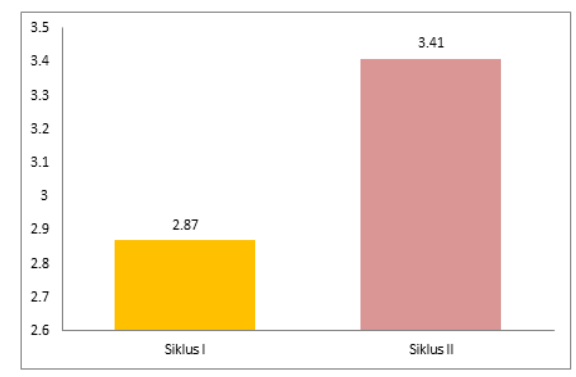

Gambar 3. Grafik Perbandingan Skor Rata-rata Aktivitas Siswa Antarsiklus

Pada kondisi awal (pratindakan) ketuntasan klasikal keterampilan menulis tegak bersambung dari 31 siswa adalah 29\% atau 9 siswa, sedangkan $71 \%$ atau 22 siswa belum mencapai ketuntasan. Nilai rata-rata kelas yaitu 57 . Nilai terendah siswa 31,5 , sedangkan nilai tertinggi yang dicapai siswa 81,5 . 
Pelaksanaan pembelajaran keterampilan menulis tegak bersambung dengan penerapan model pembelajaran Explicit Instruction menghasilkan hasil yang berbedabeda pada setiap siklusnya. Pada siklus I ketuntasan klasikal meningkat menjadi $61 \%$ atau 19 siswa, sedangkan $39 \%$ atau 12 siswa belum mencapai ketuntasan. Nilai ratarata kelas meningkat menjadi 69,12, nilai terendahnya 44 dan nilai tertingginya 83 . Pada siklus I belum mencapai indikator kinerja yang ditetapkan yakni $80 \%$ dari 31 siswa mencapai KKM (70), sehingga dilanjutkan ke siklus berikutnya. Adanya peningkatan keterampilan menulis tegak bersambung siswa dipengaruhi oleh kinerja guru dan aktivitas siswa selama pembelajaran. Berdasarkan hasil observasi kinerja guru pada siklus I menunjukkan bahwa kinerja guru termasuk dalam kategori baik yakni dengan skor rata-rata 2,98. Selain itu, berdasarkan hasil observasi pembelajaran dengan menerapkan model pembelajaran Explicit Instruction juga dapat melibatkan siswa secara aktif dan meningkatkan aktivitas siswa selama pembelajaran. Pada siklus I skor rata-rata aktivitas siswa adalah 2,87 (kategori baik). Pembelajaran pada siklus I sudah berlangsung dengan baik, tetapi ada beberapa kekurangan yang berasal dari guru dan siswa. Faktor dari guru yaitu kurang dapat menguasai kelas, pelaksanaan pembelajaran belum sesuai dengan alokasi waktu yang direncanakan, penggunaan media masih belum menarik siswa, dan kurang terbuka dalam memberikan respons kepada siswa. Faktor dari siswa yaitu: masih ada beberapa siswa yang belum memahami kaidah penulisan, beberapa siswa kurang terlibat aktif, kurang antusias dan kurang berani menjawab maupun berpendapat. Kemudian, kekurangan-kekurangan tersebut dianalisis dan dijadikan refleksi untuk perbaikan di siklus II.

Pelaksanaan siklus II didasarkan pada hasil analisis data dan refleksi siklus I. Pada siklus II ketuntasan klasikal keterampilan menulis tegak bersambung siswa mencapai $84 \%$. Ini berarti sudah melebihi indikator kinerja yang ditetapkan. Nilai ratarata kelas pada siklus II sebesar 80,42 dengan nilai tertingginya 95,5 dan nilai terendahnya 58. Adanya peningkatan nilai keterampilan menulis tegak bersambung siswa juga dipengaruhi oleh kinerja guru dan aktivitas siswa. Melalui penerapan model pembelajaran Explicit Instruction, kinerja guru di siklus II mengalami peningkatan dari siklus I dengan skor rata-rata 3,33 (dalam kategori sangat baik). Aktivitas siswa pada siklus II juga mengalami peningkatan sehingga skor rata-ratanya menjadi 3,41 dengan kategori sangat baik. Adanya peningkatan tersebut dikarenakan peneliti mengadakan perbaikan-perbaikan pada kekurangan yang ada. Peneliti mengefektifkan penggunaan media melalui variasi media dengan menambahkan media lain seperti kartu huruf, DorBlat dan flashcard. Selain itu, meningkatkan kemampuan mengelola kelas dengan menciptakan pembelajaran yang lebih menarik dan membuat siswa semakin aktif, meningkatkan pemberian respons terhadap siswa yang bertanya dan menjawab, dan memperbaiki pembagian waktu pada penerapan langkah-langkah model pembelajaran Explicit Instruction.

Berdasarkan hasil temuan dan data yang telah dipaparkan oleh peneliti dan didukung oleh teori yang telah diuraikan sebelumnya, penelitian dengan menerapkan model pembelajaran Explicit Instruction dapat meningkatkan aktivitas dan nilai keterampilan menulis tegak bersambung siswa. Ketercapaian pada peningkatan keterampilan menulis tegak bersambung pada siswa tidak bisa terlepas dari model pembelajaran yang digunakan. Seperti yang diungkapkan Rosenshine (Archer dan Hughes, 2011) bahwa:

"Explicit Instruction is characterized by a series of supports or scaffolds, whereby students are guided through the learning process with clear statements about the purpose and rationale for learning the new skill, clear explanations and demonstrations of the instructional target, and supported practice with feedback until independent mastery has been achieved."

Explicit Instruction dicirikan sebagai serangkaian dukungan atau perancah, dimana siswa dipandu melalui proses belajar dengan pernyataan yang jelas tentang 
tujuan dan alasan untuk mempelajari keterampilan baru, penjelasan yang jelas dan demosntrasi dari target instruksional, dan dukungan latihan dengan umpan balik sampai penguasaan independen telah tercapai. Dengan menerapkan model pembelajaran Explicit Instruction siswa akan memperoleh penjelasan dan demonstrasi yang dirancang guru berdasarkan target, serta diiringi dengan latihan terbimbing dan umpan balik pada akhir pembelajarannya untuk mengetahui perkembangan siswa.

Berdasarkan hasil analisis data nilai keterampilan menulis tegak bersambung siswa, aktivitas siswa, dan kinerja guru yang diperoleh melalui penelitian dengan menerapkan model pembelajaran Explicit Instruction pada pembelajaran keterampilan menulis tegak bersambung menunjukkan adanya peningkatan. Indikator kinerja yang dicapai telah melebihi indikator kinerja yang ditetapkan yakni $84 \%$ dari 31 siswa mencapai ketuntasan.

\section{SIMPULAN}

Berdasarkan hasil penelitian tindakan kelas yang dilaksanakan dalam 2 siklus pada pembelajaran menulis tegak bersambung melalui model pembelajaran Explicit Instruction, dapat ditarik kesimpulan bahwa penerapan model pembelajaran Explicit Instruction dapat meningkatkan nilai keterampilan menulis tegak bersambung siswa kelas II SD Negeri Soropadan No. 108 Surakarta tahun ajaran 2017/2018. Pada pratindakan nilai rata-rata keterampilan menulis tegak bersambung pada 31 siswa adalah 57 dengan ketuntasan klasikal sebesar $29 \%$ atau 9 siswa, meningkat menjadi 69,12 pada siklus I dengan ketuntasan klasikal $61 \%$ atau 19 siswa, dan meningkat menjadi 80,42 pada siklus II dengan ketuntasan klasikal $84 \%$ atau 26 siswa mencapai KKM $(\geq 70)$. Secara teoritis hasil penelitian ini dapat digunakan sebagai bahan referensi untuk penelitian yang sejenis. Model pembelajaran Explicit Instruction sesuai diterapkan dalam pembelajaran keterampilan menulis tegak bersambung karena dapat melibatkan siswa secara aktif dan mengasah keterampilan siswa melalui pengalaman latihan secara langsung.

Berdasarkan simpulan dan implikasi di atas, peneliti memberikan beberapa saran yang ditujukan kepada:

1. Bagi sekolah hendaknya memberikan dukungan dan memfasilitasi guru dalam menerapkan model pembelajaran inovatif dan mendorong guru melakukan penelitian tindakan kelas.

2. Bagi guru yang mengajarkan keterampilan menulis tegak bersambung, pembelajaran menggunakan model Explicit Instruction dapat dijadikan sebagai salah satu alternatif solusi.

3. Bagi peneliti lain, hendaknya menambahkan variasi-variasi tindakan agar meningkatkan efektivitas dan kualitas pembelajaran yang diharapkan, serta menambahkan kajian-kajian teori yang lebih banyak.

\section{DAFTAR PUSTAKA}

Abdurrahman, M. (2012). Anak Berkesulitan Belajar: Teori, Diagnosis, dan Remediasinya. Jakarta: PT Rineka Cipta.

Archer, A. L. \& Hughes, C. A. (2011). Explicit Instruction: Effective and Efficient Teaching. New York: The Guilford Press.

Eggen, P \& Kauchak, D. (2012). Stategi dan Model Pembelajaran. Terj: S. Wahono. Jakarta: PT. Indeks.

Indira, A. \& Vijayan, P. (2015). Teaching Cursive Hand Writing As An Intervention Strategy For High School Children With Dysgraphia. International Journal of Social Sciences.

Rukayah. (2013). Pedoman Pelaksanaan Pembelajaran Menulis dengan Pendekatan Whole Language di Sekolah Dasar. Surakarta: UNS Press.

Sharp, L. \& Brown, T. (2015). Handwriting Instruction: An Analysis of Perspectives from Three Elementary Teachers. Texas Journal of Literacy Education. 
Tompkins, G. E. \& Hoskisson, K. (1991). Language Arts Content and Teaching Strategies. New York: Macmillan Publishing Company.

Zulela. (2012). Pembelajaran Bahasa Indonesia: Apresiasi Sastra di Sekolah Dasar. Bandung: Remaja Rosdakarya. 